\title{
Latvian Consumers' Knowledge about Genetically Modified Organisms
}

\begin{abstract}
The aim of this investigation is to present the results obtained during the survey of Latvian consumers in order to elicit subjective and objective knowledge about genetically modified organisms and genetic modification. The main task was to develop the core questions so that to elicit the objective knowledge of Latvian consumers on genetically modified organisms. The questions were elaborated in cooperation with Latvian scientists in the field of biology and further will be incorporated in the survey on Latvian consumers' attitude regarding the use of genetically modified organisms in food production and other industries where also relationship between the level of the consumers' knowledge and attitude to acceptance of genetically modified products will be evaluated.
\end{abstract}

Keywords: consumer attitude, knowledge, genetically modified.

Šio tyrimo tikslas yra pristatyti rezultatus, kurie buvo gauti apklausus Latvijos vartotojus, siekiant išsiaiškinti jų subjektyvias ir objektyvias žinias apie genetiškai modifikuotus organizmus bei genetinę modifikaciją. Pagrindine užduotis buvo suformuluoti esminius klausimus, kurie leistų išsiaiškinti Latvijos vartotojų objektyvias žinias apie genetiškai modifikuotus organizmus. Klausimai apklausoje pasirinkti bendradarbiaujant su Latvijos biologijos srities mokslininkas ir šie klausimai taip pat bus ịtraukti ị apklausą tiriant Latvijos vartotoju požiūrị ị modifikuotų organizmu panaudojima maisto gamyboje ir kitose pramonès šakose, kuris irgi siekia ịvertinti ryšị tarp vartotojų žinių ir požiūrio ị genetiškai modifikuotus produktus.

Raktiniai žodžiai: vartotojų požiūris, žinios, genetiškai modifikuotas.

\section{Introduction}

The research results show that perceived benefits had the most important influence on consumer purchase decisions, such as environmental impact and health related concerns (Fortin, Renton, 2003). But perception of the possible benefits depends on knowledge of the consumer on a respective topic.

According to A. Kayabası and B. Mucan (2011), the attitudes and perceptions of the consumers towards genetically modified food have nine dimensions: the perceived environmental risk, the perceived benefit, long-term effects on human health, risk for the world, attitudes towards labeling, attitudes towards purchase, attitudes in terms of cultural-spiritual and moral values, perception of knowledge level and the perceived risk respectively. The most explanatory factor is the possible risks of genetically modified food on human health in the long term. The least explanatory factor solution is the attitudes towards cultural-spiritual and moral values. Additionally another important result provided 
by the research is that the consumers do not have sufficient information regarding genetically modified food. It was found out that consumers have medium level of knowledge about gene technology.

It is not questionable that the level of knowledge plays an important role in consumer decisions. For example according to S. Bonny (2003), acceptability of genetically modified products depends on many factors related to perception of risks and to the importance of benefits that justify or offset them. But risk perception of genetically modified organisms have been extended to a very wide field, including many socio-economic or political aspects, knowledge of the risk and familiarity with it, scientific uncertainty, controversy, delay in the appearance of undesirable consequences, advantages - or disadvantages - for the person exposed etc.

The impact of knowledge on consumer decision and acceptance of genetically modified products is an important issue for different stakeholders: policy makers, agribusinesses, and other parties interested in the acceptance (or rejection) of genetically modified products. When investigating these subjects, it is important to be careful of the differences between objective and subjective knowledge. Both measures may be important factors in willingness to accept new products; however, according to L. House et al. (2004), they may impact acceptance differently.

It is often argued that consumers' education will improve acceptance of biotechnology (e.g., Hoban and Katic, 1998). For example according to I. Aleksejeva (2014) the most of the EU experts involved in genetically modified organisms' decision making process are supportive towards the use of genetically modified organisms in food and feed and many of them consider that genetically modified food/ feed is as safe as conventional products or more safe than unsafe. The experts are more concerned about cultivation of genetically modified plants as consider they can cause risk to environment.

The assumption of the genetic modification proponents is that, if citizens better understand the science and biotechnology underlying genetically modified food benefits, they are more likely to accept genetically modified food research, development, and commercialization (e.g. Allum et al., 2002; Evans and Durant, 1995). Although other research, especially in Europe (e.g. Gaskell et al., 2003), has called into question this understandable inference from the knowledge deficit model.

To improve understanding and acceptance of biotechnology it is necessary to find the balance between credible and sciencebased information, then communicating this information through a variety of channels. The impact of knowledge on consumers' acceptance of genetically modified products has been measured in a number of studies with contradictory results. One potential explanation for the existing differences is the manner in which knowledge is measured. (House et al, 2004).

However, the level of knowledge of the consumers regarding genetic engineering varies in different parts of the world. For example, according to the investigation of Z. Xiaoyong et al. (2010) a basic quiz of six questions concerning biotechnologies was given to respondents in China, the US and the EU. By comprising the test results among these consumers it was concluded that there are statistical differences between Chinese consumers and EU consumers indicating that Chinese consumers are more knowledgeable regarding issues concerning biotechnology than 
their EU counterparts whilst remaining less knowledgeable about biotechnology issues than consumers in the US. It remains a universal phenomenon that consumers have very limited knowledge regarding biotechnology. This suggested that consumers' attitudes toward genetically modified foods could be influenced by new information supplied and knowledge gained.

The impact of knowledge on decisionmaking, and the measurement of this variable, has long been a subject in marketing literature. C. W. Park and V. P. Lessig (1981) identify two major approaches for measuring product familiarity: one measuring how much a person knows about the product and the other measuring how much a person thinks they know about a product. Similarly, M. Brucks (1985) describes three categories of consumer product class knowledge used in consumer behavior research: subjective knowledge, the individual's perception of how much s/he knows; objective knowledge, a measure what an individual actually knows; and prior experience, the amount of purchasing or usage experience the consumer has with the product. However, according to M. Brucks (1985) experience-based measures of knowledge are less directly linked to behaviour.

\section{Research results and discussion}

When we consider decision making regarding the purchasing of genetically modified products we can presume that this decision is impacted by the consumers' subjective knowledge about genetically modified organisms and awareness (labelling) regarding these products. In the EU the labelling of genetically modified pro- ducts is mandatory and each consumer has the freedom of choice to purchase such products or not.

Previous researchers have asserted that subjective knowledge is a stronger motivator of consumer behavior than objective knowledge.

C. V. Park et al. (1994) found that product-related experience is more strongly related to subjective knowledge than objective knowledge.

P. S. Raju et al. (1995) found that, of the three types of knowledge (subjective knowledge, objective knowledge, and usage experience), subjective knowledge is the most closely associated with purchase decision satisfaction. This is because those who have greater subjective knowledge are likely to feel less confused and more certain about the quality of their choice, implying that subjective knowledge is an important factor in consumer decision making.

In the list of the articles and literature on consumers' attitude and acceptance of genetically modified organisms the significant difference is observable concerning the impact of the consumers' knowledge on such attitude or acceptance. One of the explanations for such difference could be the method of the measurement of the consumers' knowledge and therefore it is important to analyse both objective (what exactly the consumer knows), and subjective (what the consumer thinks he knows) knowledge.

For example, according to C. W. Park et al. (1994) objective knowledge is defined as accurate information regarding the product class stored in long-term memory, while subjective knowledge is an individual's perceptions of what or how much he or she knows about a product class, also known as self-assessed knowledge. 
According to findings of R. F. Durant and J. S. Legge (2005) the EU citizens with higher objective scientific knowledge about genetically modified foods are the most conflicted in their attitudes. Thus, instead of greater scientific knowledge enhancing support for genetically modified foods, respondents with greater knowledge seem less able to decide one way or the other. American scientists admonish that this finding does not necessarily prove that, as consumers receive more information about the scientific and biotechnological foundations of genetically modified food benefits, they will be more or less supportive of genetically modified foods, or that they will become more conflicted about them. The scientists are sure that such a conclusion requires a series of pre-test/post-test experimental designs with comparison groups.

According to I. B. Christoph et al. (2008) knowledge is also often found to influence the attitudes of the consumers towards genetically modified organisms. However, the direction of influence remains unclear. Analysing the list of the studies it is possible to conclude that the results are contradictious. For example in 1997 Hoban wrote that the low acceptance for genetically modified products is a result of consumers' little knowledge about biotechnology. The same conclusions were made by $\mathrm{P}$. Ganiere, et al. (2006) and S. Ghasemi et al. (2013). Although in the findings of J. Scholderer and L. J. Frewer (2003) it was concluded that additional information decreases acceptance. These results are in accord with results in B. Onyango et al. (2004), who found that people with good technological knowledge are more likely to be opponents of biotechnol- ogy. While M. Rodríguez-Entrena and M. Salazar-Ordóñez (2013) affirm that among a great deal of literature that has been studied relating cognitive and attitudinal factors conditioning consumers' acceptance of genetically modified food, knowledge being one of the most inconsistent variables.

But according to Hyun Joung Jin and Dae Hee Han (2014) people with less knowledge are more likely to panic due to mass media reports regarding a food hazard issue. More informed consumers have less dramatic responses to food safety issues compared to less informed people.

Although according to $\mathrm{H}$. I. Miller and G. Conko (2000) concern as regards genetically modified organisms cannot simply be imputed to a lack of knowledge in biology, as many actors arguing for better education of the public have done.

To elicit Latvian consumers' knowledge on genetically modified products, the questions were conducted in cooperation with Latvian scientists in the field of biology. The main aim of the survey was to obtain data to measure level of Latvian consumers on domain of interest and to find the difference between objective and subjective knowledge of the consumers.

To obtain this goal based on the literature on consumer perception of risks and benefits the series of 8 true/false questions were elaborated to measure the objective knowledge of the consumers.

The respondents (randomly selected from all age groups and with different education level) were asked to answer the questions. The data obtained are presented in Table 1.

The table lists the item along with the percentage of respondents who gave the 
Objective knowledge of Latvian consumers concerning genetically modified organisms

\begin{tabular}{|l|l|c|}
\hline \multicolumn{1}{|c|}{ No. } & \multicolumn{1}{|c|}{ Question } & Percentage correct \\
\hline 1. & $\begin{array}{l}\text { Toxic and allergic reaction can be caused by both GM food, and any } \\
\text { other food }\end{array}$ & 95.5 \\
\hline 2. & Tomatoes modified with fish genes taste fishy & 90.9 \\
\hline 3. & Every day a man with food takes a lot of different foreign genes & 86.4 \\
\hline 4. & It is not possible to transfer animal genes to plants & 68.2 \\
\hline 5. & $\begin{array}{l}\text { By eating genetically modified tomato, a person's genes could also be } \\
\text { changed }\end{array}$ & 59.1 \\
\hline 6. & Genetically modified animals always are bigger than ordinary one & 54.5 \\
\hline 7. & $\begin{array}{l}\text { Ordinary tomato does not contain genes, but genetically modified } \\
\text { tomato does }\end{array}$ & 50.0 \\
\hline 8. & $\begin{array}{l}\text { Genetically modified food genes can get into the human generative } \\
\text { cells and can be passed to future generations }\end{array}$ & 31.8 \\
\hline
\end{tabular}

Source: the author's elaborated questions based on the results obtained from the survey in February, 2014.

correct answer. Some of the items are disappointing in terms of the objective knowledge exhibited. For example, a half $(50.0 \%)$ of the sample believe that 'ordinary tomato does not contain genes, but genetically modified tomato does' and only $31.8 \%$ knows that 'by eating genetically modified food genes cannot get into the human generative cells and be passed to future generations. On the other hand the respondents were well informed $(95.5 \%)$ that 'toxic and allergic reaction can be caused by both genetically modified food, and any other food' and that 'tomatoes modified with fish genes don't taste fishy' (90.9\%).

To measure subjective knowledge the respondents were asked to rate their knowledge using the scale from 1 to 10 about genetically modified organisms and genetic modification, where $1-n o t$ at all knowledgeable and 10 - extremely knowledgeable.

The data were collected on responses to 10 point scale (Figure 1). Accord- ing to the data obtained during the pilot test it is not possible to find out now the subjective knowledge of Latvians in general as the number of the respondents are not representative, but as we can see from the pilot test the respondents were enough critical to assess the level of their knowledge. The most of the respondents $(22.7 \%)$ assessed their knowledge about genetically modified organisms and genetic modification with 6 and it is the highest rate among the respondents. $18.2 \%$ of the respondents assessed their knowledge with 1, 3, 4 and 5 .

In the further investigation performing the survey on Latvian consumers' attitude regarding the use of genetically modified organisms in food production and other industries it will be appropriate to collect data about the education, age, religion and location of the respondents to obtain more detailed and comparative results regarding level of objective and subjective knowledge about genetically 


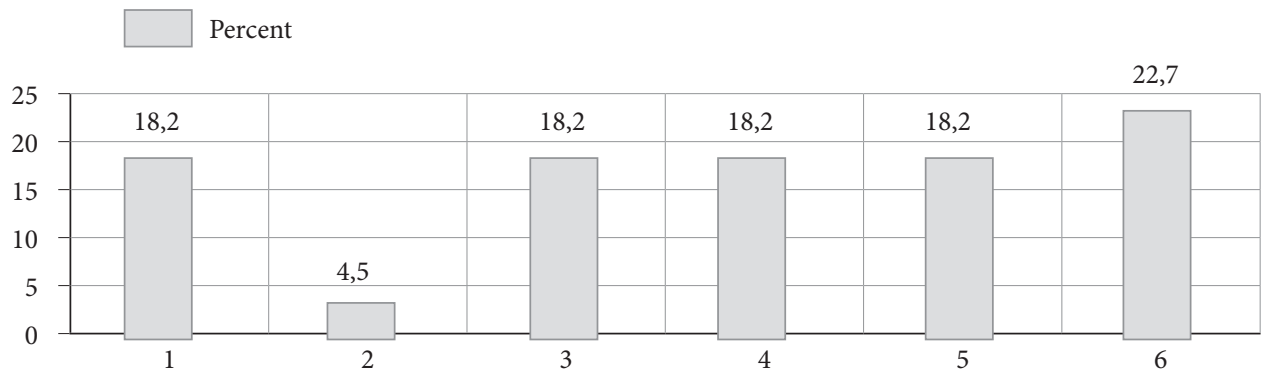

Fig. 1. Subjective knowledge of genetic modification. Respondents answered the following question: "How knowledgeable would you say you are about genetically modified organisms and genetic modification?"

Source: elaborated by the author based on the results obtained from the survey in February, 2014

modified organisms and genetic modification among Latvians.

It is also important to note that consumers are particularly conservative when it comes to perception and acceptance of foods compared to other products. Benefit-risk evaluations tend to be skewed towards acceptance of all that is traditional and well-known (benefits), and rejection or suspicion towards anything that is novel or highly processed (risks) regardless of actual risk (Ueland et al., 2012).
As it is shown in Table 2 the resources from which information on possible benefits and risks of genetically modified organisms is obtained mostly are the internet followed by TV and then Radio. The resource from which information is obtained the least has been determined as books and scientific papers. No one of the respondents indicated informative seminars and events as the resource of the information.

It is important to mention that just $13.6 \%$ of the respondents use scientific

The resources from which information on GMOs is obtained

Table 2

\begin{tabular}{|c|l|c|}
\hline No. & \multicolumn{1}{|c|}{ Information resources } & Share of respondents (\%) \\
\hline 1. & Internet resources & 77.3 \\
\hline 2. & TV & 63.6 \\
\hline 3. & Friends, relatives and acquaintances & 54.5 \\
\hline 4. & Radio & 36.4 \\
\hline 5. & Newspapers and magazines & 22.7 \\
\hline 2. & Books & 4.5 \\
\hline 6. & Scientific papers & 13.6 \\
\hline 7. & Informative events and seminars & - \\
\hline
\end{tabular}

Source: elaborated by the author based on the results obtained from the survey in February, 2014. 
papers to obtain information about genetically modified organisms and genetic modification which we can presume as scientifically proved and objective. Other resources of the information we cannot presume as objective information but just interpretation of the media and subjective attitude of the people. It is a very important aspect when we analyse the subjective knowledge of the respondents.

\section{Conclusions}

This paper represents the research investigating the level of the knowledge of Latvians in the field of genetically modified organisms and genetic modification.

The review of the literature regarding relationship between knowledge and acceptance of genetically modified products is provided and it is evident that consumers are particularly conservative when it comes to perception and acceptance of genetically modified organisms and their choice is based on their presumed risk/benefit evaluation.

In collaboration with Latvian scientists in the field of biology 8 true/false questions were developed to elicit the objective knowledge of Latvian consum- ers regarding genetically modified organisms and genetic modification.

In the further investigation performing the survey on Latvian consumers' attitude regarding the use of genetically modified organisms in food production and other industries it will be appropriate to collect data about the education, age, religion and location of the respondents to obtain more detailed and comparative results regarding level of objective and subjective knowledge about genetically modified organisms and genetic modification among Latvians.

Just $13.6 \%$ of the respondents use scientific papers to obtain information about genetically modified organisms and genetic modification which we can presumed as scientifically proved and objective. Other resources of the information we can't presume as objective information but just interpretation of the media and subjective attitude of the people.

The elaborated survey further will be incorporated in the survey on Latvian consumer attitude regarding the use of genetically modified organisms in food production and other industries to find relationship between level of the knowledge and support of genetically modified products among Latvian consumers.

\section{References}

1. Aleksejeva, I. (2014). EU experts' attitude towards use of GMO in food and feed and other industries // Procedia - Social and Behavioral Sciences. Vol. 110, pp. 494-501.

2. Allum, N. C., Boy, D., Bauer, M. W. (2002). European Regions and the Knowledge Deficit Model, in M. Bauer and G. Gaskell (eds.) Biotechnology: The Making of a
Global Controversy, pp. 224-43. Cambridge: Cambridge University Press.

3. Bonny, S. (2003). Why are most Europeans opposed to GMOs? Factors explaining rejection in France and Europe // Electronic Journal of Biotechnology ISSN: 0717-3458. Vol. 6, No. 1. 
4. Brucks, M. (1985). The Effects of Product Class Knowledge on Information Search Behavior // Journal of Consumer Research. Vol. 12, No. 6, pp. 1-16.

5. Christoph, I. B., Bruhn, M., Roosen, J. (2008). Knowledge, attitudes towards and acceptability of genetic modification in Germany // Appetite. Vol. 51, No. 1, pp. 58-68.

6. Durant, R. F, Legge, J. S. (2005). Public Opinion, Risk Perceptions, and Genetically Modified Food Regulatory Policy // European Union Politics. Vol. 6, No. 2, pp. 181-200.

7. Evans, G., Durant, J. (1995). The Relationship between Knowledge and Attitudes in the Public Understanding of Science in Britain // Public Understanding of Science. Vol. 4, pp. 57-74.

8. Fortin, D. R., Renton, M. S. (2003). Consumer Acceptance of Genetically Modified Foods in New Zealand // British Food Journal. Vol. 105, No. $1 / 2$, pp. $42-58$.

9. Ganiere, P., Chern, W. S., Hahn, D. (2006). A continuum of consumer attitudes towards genetically modified foods in the US // Journal of Agricultural and Resource Economics. Vol. 31, No. 1, pp. 129-149.

10. Gaskell, G., Allum, N., Stares, S. (2003). Europeans and Biotechnology in 2002: A Report to the EC Directorate General for Research from the Project "Life Sciences in European Society”, QLG7-CT-1999-00286, Eurobarometer 58.0, 2nd ed., 21 March.

11. Ghasemi, S., Karami, E., Azadi, H. (2013). Knowledge, attitudes and behavioral intentions of agricultural professionals toward genetically modified (GM) foods: a case study in Southwest Iran // Science and Engineering Ethics. Vol. 19, No. 3, pp. 1201-1227. doi: 10.1016/j.appet.2012.09.028.

12. Hoban, T. J. (1997). Consumer acceptance of biotechnology: An international perspective // Nature Biotechnology. Vol. 15, pp. 232-234.

13. Hoban, T., Katic, L. (1998). American consumer views on biotechnology // Cereal Foods World. Vol. 43, No. 1, pp. 20-22.

14. House, L., Lusk, J., Jaeger, S., Traill, W. B., Moore, M., Valli, C., Morrow, B., Yee, W. M. S. (2004). Objective and Subjective Knowledge: Impacts on Consumer Demand for Genetically Modified Foods in the United States and the European Union // AgBioForum. Vol. 7, No. 3, pp. 113-123.
15. Hyun Joung Jin, Dae Hee Han (2014). Interaction between message framing and consumers' prior subjective knowledge regarding food safety issues // Food Policy. Vol. 44, pp. 95-102.

16. Kayabası, A., Mucan, B. (2011). An Empirical Study of Consumer Attitudes and Perceptions Toward Genetically Modified Foods (GMF) // European Journal of Social Sciences. Vol. 25, No. 1, pp. 52-65.

17. Miller, H. I., Conko, G. (2000). The science of biotech meets the politics of global regulation// Issues in Science and Technology. Vol. 17, No. 1, pp. 47-54.

18. Onyango, B., Govindasamy, R., Hallman, W., Jang H. M., Puduri, V. S. (2004). Consumer acceptance of genetically modified foods in Korea: Factor and cluster analysis. - Working Paper No. WP-1104-015, New Jersey: Food Policy Institute, Rutgers University.

19. Raju, P. S., Lonial, S. C., Mangold, W. G. (1995). Differential effects of subjective knowledge, objective knowledge, and usage experience on decision making: an exploratory investigation //Journal of Consumer Psychology. Vol. 4, No. 2, pp. 153-180.

20. Rodríguez-Entrena, M., Salazar-Ordóñez, M. (2013). Influence of scientific-technical literacy on consumers' behavioural intentions regarding new food // Appetite. Vol. 60, No. 1, pp. 193-202. doi: 10.1016/j. appet.2012.09.028.

21. Scholderer, J., Frewer, L. J. (2003). The biotechnology communication paradox: Experimental evidence and the need for a new strategy // Journal of Consumer Policy. Vol. 26, pp. 125-157.

22. Park, C. W., Lessig, V. P. (1981). Familiarity and its Impacts on Consumer Decision Biases and Heuristics // Journal of Consumer Research. Vol. 8, No. 9, pp. 223-230.

23. Park, C. W., Mothersbaugh, D. L., Feick, L. (1994). Consumer knowledge assessment // Journal of Consumer Research. Vol. 21, No. 2, pp. 71-82.

24. Pew Initiative on Food and Biotechnology (2001). Pew initiative on food and biotechnology finds public opinion about genetically modified foods 'up for grabs. Washington, DC: Pew Charitable Trusts. Internet access: <http://www.pewtrusts.com> [accessed June 1, 2014]. 
25. Ueland, Ø., Gunnlaugsdottir, H., Holm, F., Kalogeras, N., Leino, O., Luteijn, J. M., Magnússon, S. H., Odekerken, G., Pohjola, M. V., Tijhuis, M. J., Tuomisto, J. T., White, B. C., Verhagen, H. (2012). State of the art in benefit-risk analysis: Consumer perception // Food \& Chemical Toxicology.
Vol. 50, No. 1, pp. 67-76. doi: 10.1016/j. fct.2011.07.066.

26. Xiaoyong, Z., Jikun, H., Huanguang, Q., Zhurong, B. (2010). A consumer segmentation study with regards to genetically modified food in urban China // Food Policy. Vol. 35, No. 5, pp. 456-462.

The paper submitted: June 16, 2014

Prepared for publication: September 02, 2014

\section{Inese ALEKSEJEVA}

\section{LATVIJOS VARTOTOJŲ ŽINIOS APIE GENETIŠKAI MODIFIKUOTUS ORGANIZMUS}

\section{S a n t r a u k a}

Latvijoje tam tikros vartotojų grupès ypač domisi genetiškai modifikuotų organizmų tema ir yra tokių vartotojų, kurie šiai problematikai yra ypač jautrūs. Latvija yra viena iš labiausiai konservatyvių šalių pasaulyje dèl savo požiūrio ị produktus gautus panaudojant genų modifikaciją, ir šis požiūris daugiausia yra susijęs su baime ir subjektyviu ịsitikinimu, kad genetiškai modifikuoti organizmai yra pavojingi bei rizikingi žmonių sveikatai

Tyrinèjant mokslinę literatūrą, kuri analizuoja vartotojų požiūrị ir palankumą genetiškai modifikuotiems organizmams, ypač išryškèja skirtumai susiję su vartotojų turimomis žiniomis ir informacija apie genetiškai modifikuotus produktus, kurios ir lemia tam tikrus ịsitikinimus. Vienas iš būdų paaiškinti tokius požiūrių skirtumus galètų būti vartotojų žinių ịvertinimo metodas, todèl būtina analizuoti tiek objektyvias žinias (ką tiksliai vartotojai žino), tiek subjektyvias (ką vartotojai galvoja, kad jie žino).

Šio tyrimo tikslas yra pristatyti rezultatus, kurie buvo gauti apklausus Latvijos vartotojus, siekiant išsiaiškinti jų subjektyvias ir objektyvias žinias apie genetiškai modifikuotus organizmus bei genetinę modifikaciją.

Pagrindinè užduotis buvo suformuluoti esminius klausimus, kurie leistų išsiaiškinti Latvijos vartotojų objektyvias žinias apie genetiškai modifikuotus organizmus. Klausimai apklausoje pasirinkti bendradarbiaujant su Latvijos biologijos srities mokslininkas jie taip pat bus ittraukti i apklausą tiriant Latvijos vartotoju požiūrị $i$ modifikuoty organizmu panaudojima maisto gamyboje ir kitose pramonés šakose, kuris irgi siekia įvertinti ryši tarp vartotojų žinių ir požiūrio ì genetiškai modifikuotus produktus.
Siekiant išsikelto tikslo buvo pasirinktos ir suformuluotos 8 teisingų ir klaidingų klausimų serijos, leidžiančios ịvertinti objektyvias vartotojų žinias. Respondentai, kurie buvo parinkti atsitiktine tvarka, ittraukiant visas amžiaus grupes su skirtingu išsilavinimu, turejo atsakyti ị klausimus. Siekiant įvertinti subjektyvias žinias respondentų buvo paprašyta îvertinti savo žinias apie genetiškai modifikuotus organizmus ir genų modifikaciją skalèje nuo 1 iki 10, kur 1 reiškè „visiškai nieko nežinau“ ir 10 - „labai gerai žinau“.

Bendradarbiaujant su Latvijos biologijos srities mokslininkais buvo suformuluoti 8 teisingi ir klaidingi klausimai, siekiant įvertinti objektyvias Latvijos vartotojų žinias apie genetiškai modifikuotus organizmus ir genų modifikaciją. Pirmieji apklausos rezultatai, vertinantys Latvijos vartotojų žinių lygị apie genetiškai modifikuotus organizmus, buvo gauti $2014 \mathrm{~m}$. vasario mèn., kai buvo atliktas bandomasis Latvijos vartotojų testas.

Kai kurie gauti atsakymų rezultatai, demonstruojantys objektyvias žinias, kelia nusivylimą. Pavyzdžiui, pusè tyrimo respondentų (50 proc.) isitikinę, kad „paprastas pomidoras neturi genų, tačiau genetiškai modifikuotas pomidoras turi genus“ ir tik 31,8 proc. apklaustųjų žino, kad „valgant genetiškai modifikuotą maistą, genai negali prasiskverbti ị žmogaus generatyvines ląsteles ir persiduoti ateities kartoms“. Kita vertus, respondentai gerai žinojo (95,5 proc.), kad „toksinę ir alerginę reakciją gali sukelti tiek genetiškai modifikuotas maistas, tiek bet koks kitas maistas“ ir, jog „modifikuotas pomidoras su žuvies genais nèra žuvies skonio" (90,9 proc.).

Remiantis gautais bandomojo testo duomenimis dabar negalima apibendrinti Latvijos 
gyventojų nuomonès apskritai, kadangi respondentų skaičius yra nereprezentatyvus, tačiau galima matyti, jog respondentai buvo pakankamai kritiški vertindami savo žinias apie genetiškai modifikuotus produktus. Dauguma respondentu (22,7 proc.) savo žinias apie genetiškai modifikuotus organizmus ir genų modifikaciją ịvertino 6 balais ir tai yra didžiausias ịvertinimas. 18,2 proc. respondentų savo žinias įvertino 1, 3, 4 ir 5 balais.

Svarbu pažymèti, kad tik 13,6 proc. respondentų žinias apie genetiškai modifikuotus organizmus ir genų modifikaciją semiasi iš mokslinių straipsnių, kuriuos mes galime vertinti kaip moksliškai pagrịstus ir objektyvius. Kitų informacijos šaltinių mes negalime vertinti kaip objektyvios in- formacijos, bet tik kaip žiniasklaidos interpretaciją ir subjektyvią žmonių nuomonę.

Detalizuota apklausa ateityje bus ịtraukta ị kitą tyrimą - Latvijos vartotoju požiūris į modifikuotu organizmu panaudojima maisto gamyboje ir kitose pramonés šakose - siekiant ịvertinti ryši tarp vartotojų žinių ir požiūrio ị genetiškai modifikuotus produktus.

Ateities tyrimai turètu orientuotis $\mathfrak{i}$ detalesnių duomenų apie respondentų išsilavinimą, amžių, religiją ir gyvenamąją vietą surinkimą, siekiant gauti daugiau išsamesnių ir palyginamųjų rezultatų apie Latvijos gyventojų objektyvias ir subjektyvias žinias susijusias su genetiškai modifikuotus organizmais ir genų modifikacija. 